DOI: 10.1515/auseur-2015-0010

\title{
State Traditions and Language Regimes: A Historical Institutionalism Approach to Language Policy
}

\author{
Selma K. SONNTAG \\ Humboldt State University \\ Linda CARDINAL \\ University of Ottawa
}

\begin{abstract}
This paper is an elaboration of a theoretical framework we developed in the introductory chapter of our co-edited volume, State Traditions and Language Regimes (McGill-Queen's University Press, 2015). Using a historical institutionalism approach derived from political science, we argue that language policies need to be understood in terms of their historical and institutional context. The concept of 'state tradition' focuses our attention on the relative autonomy of the state in terms of its normative and institutional traditions that lead to particular path dependencies of language policy choices, subject to change at critical junctures. 'Language regime' is the conceptual link between state traditions and language policy choices: it allows us to analytically conceptualize how and why these choices are made and how and why they change. We suggest that our framework offers a more robust analysis of language politics than other approaches found in sociolinguistics and normative theory. It also challenges political science to become more engaged with scholarly debate on language policy and linguistic diversity.
\end{abstract}

Keywords: state, language policy, language regime, historical institutionalism, linguistic diversity

Language policies are eminently political. They can reinforce or diffuse conflict between language groups, function as instruments of inclusion or exclusion, promote solidarity or stoke intolerance, and play a role in civil strife and war or contribute to peace and intercultural dialogue. They can have a significant impact on people's lives, in schools, in public services, in the economy, in the daily plebiscite that Ernest Renan so famously evoked. They can determine the criteria for community membership, be it local, regional, national, or global; likewise, they can discriminate against linguistic minorities and immigrant groups. They can accelerate language loss, just as they can favour revitalization and empowerment of linguistic minorities. 
We can group most studies of language policy under the rubric of sociolinguistic and normative approaches. These approaches guide a large part of the research on the vitality of languages (see, e.g. Nettle and Romaine 2000; Gilbert 2010), the multiple facets of linguistic landscapes (see, e.g. Gorter 2006; Kihato et al. 2010), and the effects of language policies on individuals and groups (see, e.g. Schiffman 1996; Fishman and Garcia 2010; Spolsky 2004). They also contribute to debate on the role of the state in governing languages and the links between nationalism, the nation-state, and minorities (see, e.g. Kymlicka and Patten 2003; May 2012). However, these approaches often neglect the analysis of the reasons for language policy choices. Even when researchers recognize the key role that the state plays in the formation of language policies, they often omit studying the how and why of language policy choices. Although there are exceptions, such as the work of Stephen May (2012) and Peter Ives (2010), for the most part, the goal of sociolinguistics and normative theory is to delineate the socio-political and normative implications of the management of linguistic diversity rather than explain language policy choices.

We propose to overcome this lacuna in the language policy literature by employing a historical institutionalism approach derived from political science, a field that has been relatively absent in language policy debates (Sonntag 1996; Safran 2010). In using historical institutionalism, we can fill in the gaps in sociolinguistic and normative approaches and reinvigorate the study of language policy within political science. We develop the analytical concepts of 'state tradition' and 'language regime' to study language policy choices within their historical and institutional context.

This article is divided into three parts. We start with situating historical institutionalism within political science and making a case for it in analysing language policy choices. In the second section, we develop the concept of state tradition, followed in the third section with that of language regime. The objective of these two latter sections is to lay the foundation of constructing a theoretical framework for analysing the how and why of language policy choices. In the conclusion, we return to the issue of linguistic diversity. Given that the majority of researchers studying language policy often grapple with the question of diversity, the theoretical framework we develop below elucidates current debate.

\section{Historical Institutionalism}

Political science has not been at the forefront of scholarship and debate on language policies. Even with the normative turn brought about by political philosophy and its recent interest in diversity issues, language policy remains understudied by political scientists. Will Kymlicka and Alan Patten's edited collection, Language Rights and Political Theory (2003), is among the few books 
in political science that treats language policy, but it does so from a political theory perspective. Our conceptual framework of state traditions and language regimes is grounded in political science, more specifically in the sub-discipline of comparative politics. Since the 1980s, public policy and state action have become a major area of research within comparative politics (Skocpol 1985; Steinmo, Thelen, and Longstreth 1992; Pierson 1994; Lecours 2005; Peters 2005). We draw upon these advances in political science and apply them to state action in the field of language policy.

When Theda Skocpol and her colleagues 'brought the state back in' to the study of politics in the 1980s (Evans, Rueschmeyer, and Skocpol 1985), the potential impact on language policy studies was substantial. Yet, few political scientists extended this new paradigm, labelled 'historical institutionalism' or 'neo-institutionalism' to the politics of language. Among comparative political scientists who did study language policy, the tendency was to use the casestudy approach, which often included a description of institutional features as background to language politics but rarely employed an institutional analysis (see, e.g. McRae 1983, 1986, 1997; Weinstein 1990; Sonntag 1991; Brown and Ganguly 2003). ${ }^{1}$ In these studies, societal groups such as linguistic minorities, and not the state or its institutions, were the focus of analysis.

Another increasingly common tendency, particularly among American comparative political scientists, was to take a rational choice approach. David Laitin's prominence in applying rational choice to language policy deserves special note. ${ }^{2}$ Laitin (e.g. 1988, 1992) lays out the 'rational' strategies employed by political elites and their mobilization of resources in the language domain. His is an ahistorical, instrumentalist approach in which all states are deemed to have an overriding imperative of rationalization and efficiency, which translates to linguistic uniformity as long as political stability is not jeopardized. Rational choice has also been criticized for assuming that ethnic groups, including linguistic groups, are just one more type of interest group. In the rational choice model, ethnicity and language are preferences and convictions rather than identities.

By taking a historical institutionalism approach, we can build on the casestudy and rational choice approaches to the study of language policy within comparative politics. Our approach allows us to theorize across case studies and to historically contextualize state action. By analysing language policy choices in

1 One political science study of language policy that did take a more institutional approach was Raymond Tatalovich's (1995) comparison of English-only legislation in different states within the United States. Given the sub-disciplinary divisions of political science in the United States, Tatalovich would be categorized as an Americanist rather than a comparativist.

2 Jonathan Pool (1990) advocates using formal modelling to analyse the relation between language regimes and political regimes. His analysis seeks to disclose the 'mechanisms that ... drive the behavior of individuals and organizations' (1990, 257), in some ways an even more ahistorical approach than other rational choice theorists. 
terms of how 'these choices are... constrained by concepts of nation and national models [i.e. state traditions] that are implicit or explicit in [political] institutions' (Bertrand 2004, 6), we can provide a more robust analysis. While sociolinguists have analysed linguistic regimes in the historical context of ideological conceptions of the nation, they have not provided an institutional context (see, e.g. Gal 2012). For comparative political scientists, especially those taking a historical institutionalism approach, the institutional context is paramount because '[a]t a fundamental level, institutions reflect a particular national model' (Bertrand 2004, 4); more specifically, 'electoral systems, legislative structures, types of executives, and federalist or unitary systems embody a certain conception of the nation or relation between nations [in a multinational state]' (Bertrand 2004, 10). To this list of institutional structures, we should add court systems (Cardinal 2015), the bureaucracy (Turgeon and Gagnon 2013), political party systems (Dupré 2015), etc. By examining the evolution of institutional responses to societal multilingualism, we can compare and contrast different 'nation' models without privileging the monolingualism of the European nation-state model.

A premise of our historical institutionalism approach is that states have complex historical and normative traditions, reflective of each state's national model, that guide and frame public policies, including language policies. Those public policies can be local, regional, national, or international. Public policy analysis, an increasingly prominent subfield of political science, when wedded to an institutional analysis (see, e.g. Corbeil 2007), can enrich the historical institutionalism approach within comparative politics. Policy analysts often focus on the broader public culture within which specific policies, including language policies, thrive or fail (see Gaspard 2015). Language policies, implemented through specific institutional pathways, play an important role in issues of economic solidarity and in the definition of new public cultures (Barbier 2012), not only at the national level but also, in Europe, at the EU level (Kraus 2008) as well as at the local and regional levels. A public policy approach can help clarify not only how language policy choices are made, but also how they interface with other public policy choices, how they are framed and implemented, what populations they target, and how categories of target populations are constructed (see Schneider and Ingram 1993). Much of the analysis of language policy from a public policy approach has been conducted by social scientists in disciplines other than political science (see, e.g. Grin (2003) in economics, Gazzola (2014) in communications, and Williams (2007) in geography), although their emphasis has been on implementation and evaluation of, and not on reasons for, language policy choices. We contend that analysing language policy as public policy through which the state governs linguistic diversity, and using a historical institutionalism approach based on the concepts of state tradition and language regime, can make a significant contribution to our understanding of language policy choices. 


\section{State Tradition}

The concept of 'state tradition' is well grounded in political science (Loughlin 2005). Our use of state tradition is informed by historical institutionalism and draws upon powerful analytical tools of comparative politics such as 'path dependency' and 'critical junctures'. Political institutions have long been an object of study in political science, although the behavioural revolution in social sciences, most apparent in the United States, effected a veering away from institutions toward the analysis of individual behaviour in the 1950s and 60s. In political science, this led to a focus on individual and group interests being the driving force in politics. The 'new' historical institutionalism of Skocpol and others refocused research on the state rather than society (Skocpol 1985; Hall and Taylor 1996). While states do react to demands and pressures from society, historical institutionalism suggests that the state has a relative degree of autonomy. That autonomy, we argue, is best defined in terms of state traditions - the institutional and normative baggage and patterns of state action. Witness France, a state born of revolution, which enacts policies today that are still justified by its Jacobin roots. India self-identifies as a post-colonial state, although the weight of colonial legacy is still visible in state actions. India also shares with Anglo-American states institutions rooted in a liberal ideology, distinct from the social democratic tradition of continental Europe. The geographic expanse of the United States, the political and linguistic landscapes of Canada, and the cultural diversity of India are the contexts for the evolution of these states' institutional structure of federalism. The relative autonomy of the state is derived from the state's normative and institutionalized traditions which mark the path that states take in policy-making. Path dependency is an analytical tool to link state traditions to policy choices.

Recent European comparative political science has used the concept of state tradition mostly in studies of 'new' territorial patterns of governance initiated by small nations and regional governments in Europe (Keating 1998; Loughlin 2005; Keating, Loughlin and Deschouwer 2003). This research demonstrates how institutions influence political actors in these small nations and regional governments (Béland and Lecours 2012; McEwen 2006). In making policy choices, these actors follow a path dependent on normative and institutional traditions. Although policy pathways may be dependent on state traditions, policy choices are often made at junctions in the path. 'Critical juncture' is an analytical tool used by political scientists to home in on pivotal points of interaction between tradition and policy. A critical juncture may be presented by social, political, economic, or environmental crises or dramatic change. Most recently, globalization has precipitated critical junctures as noted by Europeanists studying small nations (see, e.g. Keating 1998). More generally, major historical 
shifts, such as decolonization, war, redrawing national borders, the dissolution of old states and the emergence of new ones, have instigated critical junctures and provoked the reinvention of state traditions. At critical junctures, new patterns of governance emerge, but never completely divorced from the old patterns and traditions in which they were formed. In other words, state traditions guide policy choices, including language policy choices, along already established pathways, but these pathways can take a different turn at times. State traditions frame how language policy choices are conceived without predetermining the specific content of these choices.

The notions of path dependency and critical junctures help flesh out the concept of state tradition in regard to language policy choices. Our concept of state tradition affords an additional element to the analysis of language policy choices. It broadens the research agenda to include analyses of language policy choices that grate against the dominant historiography of the nation-state in which homogeneity and uniformity are privileged by demonstrating the existence of other path dependencies formed at critical junctures (Albaugh 2014; Cardinal and Sonntag 2015; Loughlin and Williams 2007). While the Canadian and Swiss cases are well known, others can also illustrate the diversity of path dependencies established by state traditions. In her study of multilingualism in education in sub-Saharan Africa, Ericka Albaugh (2014) notes the absence of compulsion toward linguistic homogeneity in most post-colonial African states. In the plurilingual situation in Algeria, state traditions inherited from colonialism compete with an emerging tradition, formed at critical junctures in the nation's recent history, which rejects this colonial heritage (see Lacoste 2007). Equally important for analysis are the post-communist cases of Eastern Europe, where state traditions formed during the Soviet era can be in conflict not only with the $19^{\text {th }}$-century European state tradition of linguistic nationalism but also with newer state traditions emerging in the context of Europeanization (see Csergo 2007), leading to different path dependencies for language policy. Hence our concept of state tradition problematizes linguistic homogenization as the singular, 'rational' pathway of the dominant nation-state model in favour of a more complex understanding of the role of state action in governing linguistic diversity. We will return to this complexity in our conclusion.

\section{Language Regime}

The concept of 'language regime' is relatively recent in the study of language policy. The best examples can be found in the work of Julien Fernand (2008) and François Grin (2007), who use the notion to describe juridical or legal aspects, as well as symbolic and functional dimensions, of language policy. Fernand (2008), 
who has surveyed 160 language regimes in the world, studies the modalities of language use in European Union communications (functional dimension), the integration of cultural elements of multilingualism in European institutions (symbolic dimension), and the forms of official recognition or the granted status of languages (juridical dimension). Grin (2007) refers to the notion of language regime in contextualizing language policies; language policies do not exist outside of a particular regime. Both Fernand and Grin use the concept of language regime for descriptive purposes. Furthermore, their work tends to conflate the notion of language regime with that of language planning. The heuristic value of their use of the concept is to further advance language planning in institutional structures such as the European Union, rather than identifying the political context in which such regimes develop.

In political science, the concept of language regime is not as well developed as that of state tradition. Amy Liu conceives of a language regime as 'the set of rules that delineate which languages can be used when and where' (Liu 2009, 24). As a political scientist who specializes in the language politics in Southeast Asia, she identifies three types of language regimes: (1) power-sharing regimes, (2) power-concentrating regimes, and (3) power-neutralizing regimes. According to Liu (2015), power-neutralizing language regimes are dependent on an exogenous lingua franca, those that are power-concentrating tend to reproduce the nationstate model, and power-sharing regimes secure the maintenance of linguistic diversity. Because she uses a rational choice approach, Liu (2015) emphasizes competing interests within political coalitions in Malaysia and Singapore in order to determine how this competition results in distinct language regimes at different critical junctures. For Liu, language regimes are the result of political competition. While her conception of language regimes as sets of rules is useful, she nevertheless neglects the institutional dimension of a language regime in favour of seeing it as simply a management tool for conflict between groups competing for political power.

In his recent book evaluating language regimes in the patent domain in Europe, Michele Gazzola conceives of a language regime as a 'particular form of public policy' (Gazzola 2014, 2). It is a 'set of rules and arrangements implemented to manage multilingual communication, typically as regards to the choice of official languages of an organization and their respective use' (Gazzola 2014, 10). Like Liu, Gazzola posits the importance of rules in his definition. In contrast, he applies the concept of language regime to organizations other than the state. In doing so, he neglects the historical and political context in which the rules and arrangements were originally adopted. Similarly to Fernand and Grin, Gazzola confines the analytical purchase of the notion of language regime to delineating specific language policy practices, although he situates rules and arrangements governing languages in their organizational and institutional context. Our notion 
of language regime offers a more encompassing concept that enables us to not only account for specific rules in a descriptive sense but also in terms of why and how these rules came about in the context of state traditions. In our conceptualization, a language regime can even mean an absence of rules: Sonntag (2015) ascribes the relative lack of rules in the American language regime to the United States' liberal laissez-faire state tradition.

Sociolinguists often attribute language policies to dominant or hegemonic ideologies such as nationalism and neo-liberalism (see, e.g. Heller and Duchêne 2012). As such, language policies, or more broadly sociolinguistic regimes (Gal 2012), serve to justify or rationalize power hierarchies and the interests of elites or majorities (see, e.g. Ricento 2000). This notion of language ideology fails to account for the institutionalization of ideologies as state traditions and the institutional path dependency of specific language policies. Instead of examining institutional pathways and critical junctures in those pathways, sociolinguists tend to analyse discursive strategies by which ideologies are represented in society (Heller and Duchêne 2007; Woolard 1985). As a result, sociolinguists who are critical of the dominant power structure often ascribe explanatory power to large 'macro sociopolitical' and 'macro-economic and political forces' (Ricento 2000, 9, 16, 20), such as globalization and imperialism (Phillipson 1992), without analysing specific political actors such as the state and its institutions or, for example, political parties as institutional intermediaries between the state and society. Nor can they account for changes in or successful challenges to dominant language ideologies.

A historical institutionalism conceptualization of language regime, in contrast, provides analytical tools to show the important relations between how language policy is ideologically conceived and how it is practised. Historical institutionalism allows us to study language regimes not only as sets of rules for governing languages and the ideologies informing language policy choices but also the links between institutional and normative state traditions and language policy choices. Our conceptualization of language regime is more robust than many of the current approaches suggest. It leads us to analyse how and why rules and representations of language policies are linked to state tradition and how and why they can change.

Our concept of 'language regime' is derived from Jane Jenson's compelling work on citizenship regimes (see, e.g. Jenson and Phillips 1996). Jenson and her colleagues use a 'neo-institutionalist approach' to analyse how the transformation in the Canadian political economy from Fordism to neo-liberalism has affected conceptions and practices of citizenship (Jenson and Phillips 2001, 71). These representations and practices of citizenship, embedded in political economy, constitute a regime.

Important to Jenson's discussion is that conceptions and practices are subject to change. She argues that conceiving of citizens as representing collectivities 
in civil society, rooted in the collectivist consensus that emerged in many Western democracies after World War II, has given way to conceiving of citizens as representing individuals. State policies have changed from responding to the needs and demands of collectivities to enabling individual agency (Jenson 2013). Individuals are empowered under neo-liberalism to make political claims on the state, which result in a dismantling of civil society, where groups of individuals with common interests were collectively empowered.

What makes Jenson's concept of citizenship regimes particularly robust is that she links how citizenship is practised to how it is conceived. Furthermore, she links state practices and conceptions to citizens' practices and conceptions. Hence, for Jenson (2000, 232), a citizenship regime is 'institutional arrangements, rules and understandings that guide and shape [not only] concurrent policy decisions ... [and] problem definitions by states,' but also 'problem definitions by ... citizens, and claims-making by citizens'. This state-society linkage 'encodes within it a paradigmatic representation' of citizens' identity and social relations between citizens and the state (Jenson and Phillips 2001, 72). In other words, a citizenship regime comprises not only institutions and rules but also a certain understanding of citizenship that informs the state's decision-making and commitments as well as the way citizens give meaning to their claims (Dobrowolsky and Jenson 2004, 156). As Jacques Bertrand (2004, 14) notes, 'the institutional environment ... defines how grievances can be expressed, repressed, or negotiated'.

In our conceptual framework, we reconfigure Jenson's concept of a citizenship regime to analyse language policy choices. We posit that a language regime refers to language practices as well as conceptions and representations of language and language use as projected through state policies and as acted upon by language users. State traditions guide and frame those practices and conceptions and these, in turn, are acted upon by language users. Consider, for the sake of simplicity, a monolingual language regime informed by a Herderian state tradition of one language equals one nation. Such a regime would define language use in terms of a single national language. Language policies would reflect that definition and, for example, restrict the medium of instruction in schools to the national language. Most language users would adhere to the conception of a single language as the national one and would act accordingly. Speakers of languages other than the national language would most likely experience language shift - that is, the intergenerational abandonment of one language by its speakers for another. In this case, language shift would indicate the 'encod[ing] of the proper and legitimate social relations' (Jenson 2000, 232) among a category of language users whose language is not recognized by state policy. These linguistic minorities are disempowered, and seek (even if unsuccessfully) empowerment by changing their language use to fit with the dominant representations. Their understanding of empowerment and their 
relationship with dominant language speakers and the state are embedded in the language regime. Language regimes empower certain language users more than others to make political claims on the state. ${ }^{3}$

This simple example presents a stable language regime. The notion of stability helps explain how seemingly contradictory relations succeed in acquiring relative permanence in time and space. Jenson $(2000,233)$ characterizes 'a stable regime as one in which the status proffered and the status anticipated match'. In the case of language regimes, if the status proffered to users of a particular language matches their anticipations, then we can expect stability. In our above example, if language shift does lead to empowerment, then we would expect the language regime to be stable. Whether there is a match or mismatch between proffered status and anticipated status is a hotly debated topic in language policy studies. Does language shift lead to economic and political empowerment for those who undertake it or is it a false promise (see Pogge 2003; May 2003)? Prominent in this debate is the case of an emerging global language regime. Does global English actually confer the status it seems to project (see Sonntag 2003; Wright 2004)?

Contradictions and inconsistencies in language regimes are often marked by specific practices and/or conceptions of language choice and use being in tension and at cross-purposes. A certain amount of contradiction can be managed within a language regime and in fact contribute to its stability. In a federal state, a language policy in effect at one level could be distinct from the language policy at another level. For example, in Canada, federal language policy is personalbased, while that of Quebec is territorial-based (Cardinal 2010). How well language policy choices articulate with other public policies, such as education, immigration, economic, and health policies, can also indicate the degree of stability and change of a language regime. In her analysis of education policy regarding foreign language teaching in France, Nuria Garcia (2015) demonstrates how discrepancies between education, immigration, and language policies are resolved within the overall gamut of a Jacobin language regime. In contrast, John Walsh (2015) suggests that coherence between language policy and other public policies in Ireland is difficult to achieve. Similarly, John Coakley (2007) notes that Ireland's language policy works with other public policies in sectors where English is so dominant that Irish plays only a symbolic role.

A mismatch between the conferred status and anticipated status of a particular language can be acceptable, as in the Irish case. However, in most cases where there is a mismatch, there is an opening for 'regime redesign'; critical to this redesign are 'strategic choices about policy and alliances' (Jenson 2000, 232).

3 Selma K. Sonntag (2010) argues that an emerging global language regime based on liberalism has legitimated individual claims for language rights. This resonates with Jenson's analysis of neo-liberalism and adds in the global dimension to our conceptual framework. 
Influential political actors can form coalitions around strategic language policy choices that effect language regime change (see Turgeon and Gagnon, 2013). Often these coalitions appear at critical junctures, when the state traditions underpinning the language regime are vulnerable and power relations reflected in status conferred in the language regime are susceptible to reconfiguration. For example, the aftermath of World War I and the enlargement of the franchise in Belgium led to a majority coalition in favour of language regime change based on enhancing the status of Flemish vis-à-vis French (Sonntag 1991). In a different example, Jean-François Dupré (2015) analyses the lack of language regime change in Taiwan despite recent democratization facilitating political bargaining and coalition-building over language policy. Taiwan's political parties proved incapable of adopting a policy favouring linguistic diversity, thus furthering the stability of the existing language regime. According to Dupré, the path dependency of Taiwan's language policy proved too enduring to allow for regime change, tied as it was to a state tradition of Mandarin dominance.

There is always a certain degree of discord between conceptions or representations of language and language use and the rules and practices of specific language policies. Ethnolinguistic mobilization can expose this discord and the discursive strategies or language ideology that masks it. This exposition through mobilization helps reconfigure how language and language use are represented in the language regime and modify language practices and policies that are institutionalized in the path dependency of the regime (see, e.g. Harguindéguy and Itçaina 2015). In this way, ethnolinguistic mobilization can disturb and disrupt power relations and, by extension, state traditions (Sonntag 1995).

In analysing incoherencies and inconsistencies, we can better understand the practices and representations of language and language use which either complement or challenge the existing language regime. The concept of language regime allows us to analyse language policy choices in terms of the underlying power relations embodied in state traditions. Along with state traditions, it provides a conceptual framework for analysing the dynamics - stability and change - of power relations and their representation in language policy.

\section{Conclusion}

In inserting a political science perspective into a field of study dominated by other social sciences, particularly by sociolinguistics, we consider it important to return to the debate on linguistic diversity. There is tendency in political science to adopt a conservative bias in the study of language policy. Political scientists, particularly in the United States, tend to assume that monolingualism is the societal norm, while linguistic diversity is a deviation from this norm. This 
assumption usually stems from ignorance and unfamiliarity - from not realizing that most people in most of the world are multilingual in their everyday lives. ${ }^{4}$

In contrast, the political science analytical framework we propose is based on the recognition that linguistic diversity is a historical and contemporary fact in many communities, regions, countries, and on a global level. Thus, despite state traditions that have fostered, particularly in Europe, monolingualism - which political scientists tend to assume is natural - and despite global linguistic homogenization - which political theorists often defend (see, e.g. Van Parijs 2011) -, linguistic diversity endures. We believe that a political science perspective, such as the one we suggest adopting, contributes to a better understanding of state language policy choices in governing linguistic diversity locally, nationally, regionally, and globally. States intervene in linguistically diverse societies at all levels, even if the conception or representation of language use framed by state tradition is that of a monolingual speaker. Our analytical concept of language regime allows us to foreground linguistic diversity despite its dismissal in most of the political science literature on language policy. In this sense, then, we are challenging political scientists to learn from their counterparts in other social sciences who are more likely to understand linguistic diversity as both an empirical reality and a normative preference (see, e.g. Kjaer and Adamo 2011; May 2012; Romaine 2015).

\section{References}

ALBAUGH, Ericka A. 2014. State-Building and Multilingual Education in Africa. New York: Cambridge University Press.

BARBIER, Jean-Claude. 2012. Languages, Political Cultures and Solidarity in Europe. Online Working Paper No 01, Helsinki: European Science Foundation. BÉLAND, Daniel-LECOURS, André. 2012. Nationalisme et protection sociale. Ottawa: Les Presses de l'Université d'Ottawa.

BERTRAND, Jacques. 2004. Nationalism and Ethnic Conflict in Indonesia. Cambridge: Cambridge University Press.

BROWN, Michael E.-GANGULY, Sumit (eds). 2003. Fighting Words: Language Policy and Ethnic Relations in Asia. Cambridge: MIT Press.

CARDINAL, Linda. 2010. Language Policy-Making and Planning in Quebec and in Canada. In: Rudy Jarrett, Stephan Gervais, Christopher Kirkey (eds), Quebec Questions. Quebec Studies for the Twenty First Century. 186-203. Oxford: Oxford University Press.

2015. State Tradition and Language Regime in Canada. In: Linda Cardinal,

4 There are, of course, exceptions to this tendency even within American political science. See Schmidt $(2000,1)$. 
Selma K. Sonntag (eds), State Traditions and Language Regimes. 29-43. Montreal: McGill-Queen's University Press.

CARDINAL, Linda-SONNTAG, Selma K. (eds). 2015. State Traditions and Language Regimes, Montreal, McGill-Queen’s University Press.

COAKLEY, John. 2007. Les majorités nationales dans les nouveaux États: relever le défi de la diversité. In: Alain-G. Gagnon, André Lecours, Geneviève Nootens (eds), Les Nationalismes majoritaires contemporains: identité, mémoire, pouvoir. 157-189. Montreal: Éditions Québec Amérique Inc.

CORBEIL, Jean-Claude. 2007. L'embarras des langues. Origine, conception et évolution de la politique linguistique québécoise. Montreal: Québec Amérique.

CSERGO, Zsuzsa. 2007. Talk of the Nation: Language and Conflict in Romania and Slovakia. Ithaca: Cornell University Press.

DOBROWOLSKY, Alexandra-JENSON, Jane Jenson. 2004. Shifting Representations of Citizenship: Canadian Politics of 'Women' and 'Children'. Social Politics 11(2): 154-180.

DUPRÉ, Jean-François. 2015. Mandarin State Tradition and Language Regime Change in Taiwan. In: Linda Cardinal, Selma K. Sonntag (eds), State Traditions and Language Regimes. 154-169. Montreal: McGill-Queen's University Press.

EVANS, Peter-RUESCHEMEYER, Dietrich-SKOCPOL, Theda Skocpol (eds).

1985. Bringing the State Back In. Cambridge: Cambridge University Press.

FERNAND Julien. 2008. Le point sur la formation des traducteurs \& interprètes dans les 12 derniers pays membres de l'U.E.: Vers une réforme du régime linguistique de l'Europe? Ph.D. diss., Université Aix-Marseilles I.

FISHMAN, Joshua A.-GARCIA, Olefia (eds). 2010. Language \& Ethnic Identity, Volume I: Disciplinary \& Regional Perspectives. $2^{\text {nd }}$ edition. Oxford: Oxford University Press.

GAL, Susan. 2012. Sociolinguistic Regimes and the Management of 'Diversity'. In: Alexandre Duchêne, Monica Heller (eds), Language in Late Capitalism: Pride and Profit. 22-42. New York: Routledge.

GARCIA, Nuria. 2015. State Traditions, Language and Education Policies in France. In: Linda Cardinal, Selma K. Sonntag (eds), State Traditions and Language Regimes. 219-236. Montreal: McGill-Queen’s University Press.

GASPARD, Helaina. 2015. Canada’s Official Languages Policy and the Federal Public Service. In: Linda Cardinal, Selma K. Sonntag (eds), State Traditions and Language Regimes. 191-204. Montreal: McGill-Queen’s University Press.

GAZZOLA, Michele. 2014. The Evaluation of Language Regimes. Theory and Application to Multilingual Patent Organisations. Amsterdam/Philadelphia: John Benjamins Publishing Company.

GILBERT, Anne (ed.). 2010. Territoires francophones: Études géographiques sur la vitalité des communautés francophones du Canada. Québec: Septentrion. 
GORTER, Durk (ed.). 2006. Linguistic Landscape: A New Approach to Multilingualism. Clevedon: Multilingual Matters.

GRIN, François. 2003. Language Policy Evaluation and the European Charter for Regional or Minority Languages. London: Palgrave Macmillan.

2007. Peut-on faire confiance au modèle ' $1+>2$ '? Une évaluation critique des scénarios de communication dans l'Europe multilingue. Revista de Llengua i Dret 45: 217-231.

HALL, Peter-TAYLOR, Rosemary. 1996. Political Science and the Three New Institutionalisms. Political Studies XLIV: 936-957.

HARGUINDÉGUY, Jean-Baptiste-ITÇAINA, Xabier. 2015. State Tradition and Regional Languages in France: The Case of Basque. In: Linda Cardinal, Selma K. Sonntag (eds), State Traditions and Language Regimes. 170-188. Montreal: McGill-Queen's University Press.

HELLER, Monica-DUCHÊNE, Alexandre. 2007. Discourses of Endangerment: Sociolinguistics, Globalization and Social Order. In: Alexandre Duchêne and Monica Heller (eds), Discourses of Endangerment: Interest and Ideology in the Defense of Languages. 1-13. London: Continuum.

2012. Pride and Profit: Changing Discourses of Language, Capital and the Nation-State. In: Language in Late Capitalism: Pride and Profit, (eds.) Alexandre Duchêne and Monica Heller, 1-21. New York: Routledge.

IVES, Peter. 2010. Cosmopolitanism and Global English: Language Politics in Globalisation Debates. Political Studies 58: 516-535.

JENSON, Jane. 2000. Restructuring Citizenship Regimes: The French and Canadian Women's Movements in the 1990s. In: Jane Jenson, Boaventura de Sousa Santos (eds), Globalizing Institutions: Case Studies in Regulation and Innovation. 231-252. Aldershot: Ashgate.

2013. Historical Transformations of Canada's Social Architecture: Institutions, Instruments, and Ideas. In: Keith Banting, John Myles (eds), Inequality and the Fading of Redistributive Politics. 43-64. Vancouver: University of British Columbia Press.

JENSON, Jane-PHILLIPS, Susan. 1996. Regime Shifts: New Citizenship Practices in Canada. International Journal of Canadian Studies 14: 111-135.

2001. Redesigning the Canadian Citizenship Regime: Remaking Institutions of Representation. In: Colin Crouch, Klaus Eder, Damian Tambini (eds), Citizenship, Markets, and the State. 69-89. Oxford: Oxford University Press.

KEATING, Michael. 1998. The New Regionalism in Western Europe: Territorial Restructuring and Political Change. Cheltenham: Edward Elgar.

KEATING, Michael-LOUGHLIN, John-DESCHOUWER, Chris. 2003. Culture, Institutions and Regional Development: A Study of Eight European Regions. A Comparative Analysis. Cheltenham: Edward Elgar. 
KIHATO, Caroline Wanjiku-MASSOUMI, Mejgan-RUBLE, Blair A.-SUBIRÓS, Pep-GARLAND, Allison M. 2010. Urban Diversity: Space, Culture, and Inclusive Pluralism in Cities Worldwide. Washington, D.C.: Woodrow Wilson Center Press; Baltimore: Johns Hopkins University Press.

KJAER, Anne Lise-ADAMO, Silvia (eds). 2011. Linguistic Diversity and European Democracy. Surrey: Ashgate.

KRAUS, Peter A. 2008. A Union of Diversity: Language, Identity and PolityBuilding in Europe. Cambridge: Cambridge University Press.

KYMLICKA, Will-PATTEN, Alan (eds). 2003. Language Rights and Political Theory. Oxford: Oxford University Press.

LACOSTE, Yves. 2007. Enjeux politiques et géopolitiques de la langue française en Algérie: contradictions coloniales et postcoloniales. Hérodote: Revue de géographie et de géopolitique 126: 17-34.

LAITIN, David D. 1988. Language Games. Comparative Politics 20: 289-302. 1992. Language Repertoires and State Construction in Africa. Cambridge: Cambridge University Press.

LECOURS, André. 2005. New Institutionalism: Theory and Analysis. Toronto: University of Toronto Press.

LIU, Amy H. 2009. The Politics of Language Regimes. Ph.D. diss. Emory University. 2015. The Politics of Language Regimes: Comparative Analysis of Southeast Asia. In: Linda Cardinal, Selma K. Sonntag (eds), State Traditions and Language Regimes. 137-153. Montreal: McGill-Queen’s University Press.

LOUGHLIN, John. 2005. Les changements de paradigmes de l'État et les politiques publiques envers les minorités linguistiques et culturelles en Europe de l’Ouest. In: Jean-Pierre Wallot (ed.), La gouvernance linguistique: le Canada en perspective. 19-38. Ottawa: University of Ottawa Press.

LOUGHLIN, John-WILLIAMS, Colin H. 2007. Governance and Language: The Intellectual Foundations. In: Colin H. Williams (ed.), Language and Governance. 57-103. Cardiff: Wales University Press.

MAY, Stephen A. 2003. Misconceiving Minority Languages Rights: Implications for Political Theory. In: Will Kymlicka, Alan Patten (eds), Language Rights and Political Theory. 123-152. Oxford: Oxford University Press.

2012. Language and Minority Rights: Ethnicity, Nationalism and the Politics of Language. $2^{\text {nd }}$ edition. New York: Routledge.

MCEWEN Nicola. 2006. Nationalism and the State: Welfare and Identity in Scotland and Quebec. Brussels: Peter Lang.

MCRAE, Kenneth D. 1983. Conflict and Compromise in Multilingual Societies. Vol. 1: Switzerland. Waterloo: Wilfrid Laurier University Press.

1986. Conflict and Compromise in Multilingual Societies. Vol. 2: Belgium. Waterloo: Wilfrid Laurier University Press. 
1997. Conflict and Compromise in Multilingual Societies. Vol. 3: Finland. Waterloo: Wilfrid Laurier University Press.

NETTLE, Daniel-ROMAINE, Suzanne. 2000. Vanishing Voices: The Extinction of the World's Languages. Oxford: Oxford University Press.

PETERS, Guy. 2005. The 'New Institutionalism'. London: Continuum.

PIERSON, Paul. 1994. Dismantling the Welfare State? Reagan, Thatcher and the Politics of Retrenchment. Cambridge: Cambridge University Press.

PHILLIPSON, Robert. 1992. Linguistic Imperialism. Oxford: Oxford University Press.

POGGE, Thomas W. 2003. Accommodation Rights for Hispanics in the United States. In: Will Kymlicka, Alan Patten (eds), Language Rights and Political Theory. 105-122. Oxford: Oxford University Press.

POOL, Jonathan. 1990. Language Regimes and Political Regimes. In: Brian Weinstein (ed.), Language Policy and Political Development. 241-261. Norwood, N.J.: Ablex.

RICENTO, Thomas. 2000. Historical and Theoretical Perspectives in Language Policy and Planning. In: Thomas Ricento (ed.), Ideology, Politics and Language Policies: Focus on English. 9-24. Amsterdam: John Benjamins.

ROMAINE, Suzanne. 2015 (forthcoming). Language and Sustainable Development: Integrating the Economics of Language Policy with Poverty Reduction and Biodiversity Conservation. In: Bengt-Arne Wickström, Michele Gazzola (eds), The Economics of Language Policy. Boston: MIT Press.

SAFRAN, William. 2010. Political Science and Politics. In: Joshua A. Fishman, Ofelia García Language (eds), \& Ethnic Identity Volume 1, Disciplinary \& Regional Perspectives. 49-69. Oxford: Oxford University Press.

SCHIFFMAN, Harold F. 1996. Linguistic Culture and Language Policy. London: Routledge.

SCHMIDT, Ronald, Sr. 2000. Language Policy and Identity Politics in the United States. Philadelphia: Temple University Press.

SCHNEIDER, Anne-INGRAM, Helen. 1993. Social Construction of Target Populations: Implications for Politics and Policy. The American Political Science Review 87(2): 334-347.

SKOCPOL, Theda. 1985. Bringing the State Back In: Strategies of Analysis in Current Research. In: Peter Evans, Dietrich Rueschemeyer, Theda Skocpol (eds), Bringing the State Back In. 3-37. Cambridge: Cambridge University Press.

SONNTAG, Selma K. 1991. Competition and Compromise amongst Elites in Belgian Language Politics. Bonn: Dümmler.

1995. Elite Competition and Official Language Movements. In: James W. Tollefson (ed.), Power and Inequality in Language Education. 91-111. Cambridge: Cambridge University Press. 
1996. Political Science and Contact Linguistics. In: Hans Goebl, Peter H. Nelde, Zdeněk Starý, Wolfgang Wölck (eds), Contact Linguistics: An International Handbook of Contemporary Research. 75-81. Berlin: Walter de Gruyter. 2003. The Local Politics of Global English. Lanham, MD: Lexington Books. 2010. La diversité linguistique et la mondialisation: Les limites des théories libérales. Politique et Sociétés 29(1): 15-43.

2015. State Tradition and Language Regime in the United States: Time for Change? In: Linda Cardinal, Selma K. Sonntag (eds), State Traditions and Language Regimes. 44-61. Montreal: McGill-Queen's University Press.

SPOLSKY, Bernard. 2004. Language Policy. Cambridge: Cambridge University Press.

STEINMO, Sven-THELEN, Kathleen-LONGSTRETH, Frank (eds). 1992. Structuring Politics: Historical Institutionalism in Comparative Analysis. New York: Cambridge University Press.

TATALOVICH, Raymond. 1995. Nativism Reborn? The Official Language Movement and the American States. Lexington: University of Kentucky Press. TURGEON, Luc-GAGNON, Alain-G. 2013. The Politics of Representative Bureaucracy in Multilingual Federations: A Comparison of Belgium, Canada and Switzerland. Regional and Federal Studies 23(4): 407-25.

VAN PARIJS, Philippe. 2011. Linguistic Justice for Europe and for the World. Oxford: Oxford University Press.

WALSH, John. 2015. The Irish Language Regime and Language Ideology in Ireland. In: Linda Cardinal, Selma K. Sonntag (eds), State Traditions and Language Regimes. 62-78. Montreal: McGill-Queen's University Press.

WEINSTEIN, Brian (ed.). 1990. Language Policy and Political Development. Norwood, N.J.: Ablex.

WILLIAMS, Colin H. 2007. Articulating the Horizons of Welsh. In: Colin H. Williams (ed.), Language and Governance. 387-433. Cardiff: University of Wales Press.

WOOLARD, Kathryn. 1985. Language Variation and Cultural Hegemony: Toward an Integration of Sociolinguistic and Social Theory. American Ethnologist 12(4): 738-748.

WRIGHT, Sue. 2004. Language Policy and Language Planning: From Nationalism to Globalisation. New York: Palgrave Macmillan. 